hemolytic streptococcal infection. J Child Neurol 1998;13: 354-356.

29. Muffat-Joly M, Barry B, Henin D, Fay M, Gehanno P, Pocidalo JJ. Otogenic meningoencephalitis induced by Streptococcus pneumoniae in gerbils. Arch Otolaryngol Head Neck Surg 1994;120:925-930.

30. Blanot S, Muffat-Joly M, Vilde F, et al. A gerbil model for rhombencephalitis due to Listeria monocytogenes. Microb Pathog 1997;23:39-48.

31. Watanabe-Ohnishi R, Aelion J, leGros L, et al. Characterization of unique human TCR V beta specificities for a family of streptococcal superantigens represented by rheumatogenic serotypes of M protein. J Immunol 1994;152:2066-2073.

32. Toyosaki T, Yoshioka T, Tsuruta Y, Yutsudo T, Iwasaki M, Suzuki R. Definition of the mitogenic factor (MF) as a novel streptococcal superantigen that is different from streptococcal pyrogenic exotoxins A, B, and C. Eur J Immunol 1996;26: 2693-2701.

33. Rikiishi H, Okamoto S, Sugawara S, Tamura K, Liu ZX, Kumagai K. Superantigenecity of helper T cell mitogen (SPM-2) isolated from culture supernatants of streptococcus pyogenes. Immunology 1997;91:406-413.

34. Vandevyver C, Mertens N, van den Elsen P, Medaer R, Raus J, Zhang J. Clonal expansion of myelin basic protein-reactive
$\mathrm{T}$ cells in patients with multiple sclerosis: restricted $\mathrm{T}$ cell receptor V gene rearrangements and CDR3 sequence. Eur J Immunol 1995;25:958-968.

35. Maillard I, Luth F, Acha-Orbea H, Diggelman H. Role of the immune response induced by superantigens in the pathogenesis of microbial infections. Parasitol 1997;115:S67-S78.

36. Herrmann T, Baschieri S, Less RK, MacDonald HR. In vivo responses of CD4+ and CD8+ cells to bacterial superantigens. Eur J Immunol 1992;22:1935-1938.

37. Herrmann T, MacDonald HR. The CD8 T cell response to staphylococcal enterotoxins. Semin Immunol 1993;5:33-39.

38. Hermans G, Denzer U, Lohse A, Raus J, Stinissen P. Cellular and humoral immune response against autoreactive $\mathrm{T}$ cells in multiple sclerosis patients after T cell vaccination. J Autoimmun 1999;13:233-246.

39. Pohl-Koppe A, Burchett SK, Thiele EA, Hafler DA. Myelin basic protein reactive Th2 T cells are found in acute disseminated encephalomyelitis. J Neuroimmunol 1998;91:19-27.

40. Genain CP, Abel K, Belmar N, et al. Late complications of immune deviation therapy in a nonhuman primate. Science 1996;274:2054-2057.

41. Franchimont D, Louis E, Dewe W, et al. Effects of dexamethasone on the profile of cytokine secretion in human whole blood cell cultures. Regul Pept 1998;73:59-65.

\title{
Neuro/mages
}
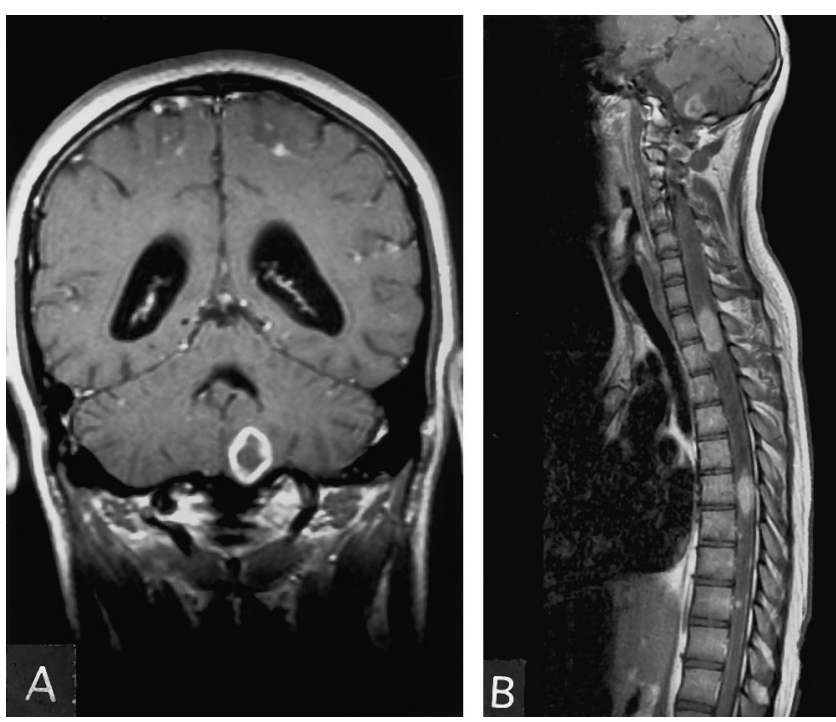

Figure. MRI at admission (postcontrast T1-weighted). (A) Ring-enhancing left cerebellar lesion and meningeal contrast enhancement. (B) Multiple intramedullary lesions.

\section{Cerebellar and medullar histoplasmosis}

M.J. Vos, MD, Y.J. Debets-Ossenkopp, $M D, P h D$,

F.A.P. Claessen, $M D$, G.J. Hazenberg, $M D$,

\section{J.J. Heimans, MD, PhD, Amsterdam, the Netherlands}

A 16-year-old Surinam boy presented with a 3-month history of progressive paraparesis and periods of fever and neck stiffness. Neurologic examination demonstrated a se- vere spastic paraparesis, Babinski signs, and sensory disturbance under level T4. The patient was not taking immunosuppressants, was HIV-seronegative, and had normal CD4 ${ }^{+}$lymphocyte counts. Postcontrast T1-weighted MRI of brain and spinal cord revealed a ring-enhancing left cerebellar lesion, meningeal contrast enhancement, and multiple intramedullary lesions (figure). CSF examination showed a lymphocytic pleocytosis, elevated total protein, lowered glucose, and negative Gram staining and cultures. Biopsy of one intramedullary lesion disclosed granulomatous lymphohistiocytic inflammation with giant cells and necrosis; cultures were positive for Histoplasma capsulatum. Some neurologic improvement occurred after sequential treatment with amphotericin B and itraconazole.

Primary neurologic presentation of histoplasmosis is extremely rare, especially in young, nonimmunocompromised hosts. Tan et al. reported a case of disseminated histoplasmosis in a 72-year-old man, which was the first report of histoplasmosis presenting as a myelopathy. ${ }^{1}$ Tabbal and Harik recently reported cerebral histoplasmosis in a 60-yearold man, presenting as a bilateral pyramidal syndrome. ${ }^{2}$

To our knowledge, this is the first case of cerebellar, meningeal, and medullar histoplasmosis reported in a young, nonimmunocompromised host. The severity of the neurologic presentation, lack of systemic manifestations, and extensiveness of CNS lesions on MRI are exceptional.

1. Tan V, Wilkins $\mathrm{P}$, Badve $\mathrm{S}$, et al. Histoplasmosis of the central nervous system. JNNP 1992;55:619-622.

2. Tabbal SD, Harik SI. Cerebral histoplasmosis. N Engl J Med 1999;340: 1176. 


\section{Neurology}

\section{Cerebellar and medullar histoplasmosis \\ Neurology 2000;54;1441 \\ DOI 10.1212/WNL.54.7.1441}

\section{This information is current as of April 11, 2000}

Updated Information \& Services

Citations

Permissions \& Licensing

Reprints including high resolution figures, can be found at: http://n.neurology.org/content/54/7/1441.full

This article has been cited by 1 HighWire-hosted articles: http://n.neurology.org/content/54/7/1441.full\#\#otherarticles

Information about reproducing this article in parts (figures,tables) or in its entirety can be found online at:

http://www.neurology.org/about/about_the_journal\#permissions

Information about ordering reprints can be found online:

http://n.neurology.org/subscribers/advertise

Neurology ${ }^{\circledR}$ is the official journal of the American Academy of Neurology. Published continuously since 1951, it is now a weekly with 48 issues per year. Copyright. All rights reserved. Print ISSN: 0028-3878. Online ISSN: 1526-632X.

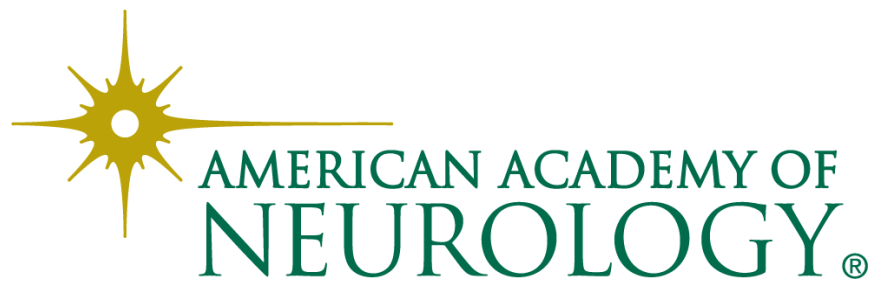

